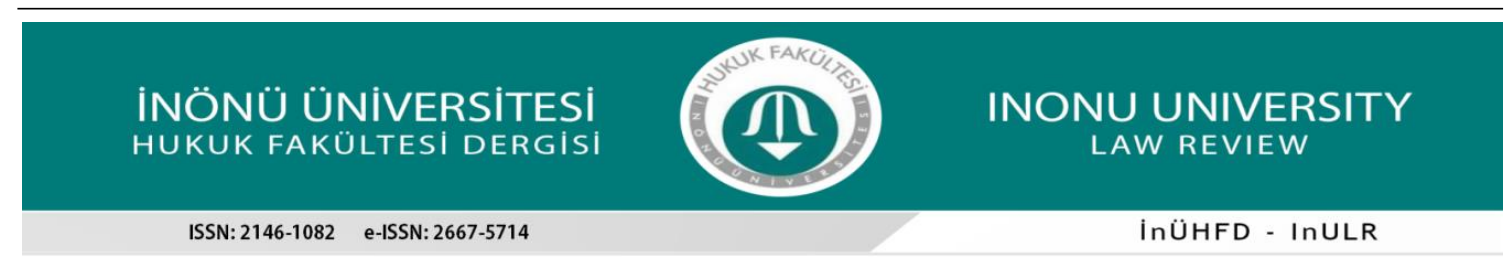

\title{
DERNEĞİN MAHKEME KARARIYLA SONA ERMESİ do
}

DISSOLUTION OF ASSOCIATION BY COURT ORDER

Makale Bilgi

Gönderilme: 22/01/2020 Kabul: $27 / 02 / 2020$

\section{Anahtar Kelimeler}

Tüzel Kişiler,

Derneğin Sona

Ermesi,

Derneğin Feshi,

Dağıtılma,

Mahkeme Kararı.

\section{Article Info}

Received: $22 / 01 / 2020$ Accepted: 27/02/2020

\section{Keywords}

Legal Persons,

Termination of

Associaition,

Dissolution of

Association,

To be Dissolved,

Court Order.

\author{
Mehmet AKÇAAL ${ }^{*} m$ (D)
}

\begin{abstract}
Özet
\end{abstract}
Dernekler, ideal bir amaçla kurulan tüzel kişiliğe sahip kişi topluluklarıdır. Söz konusu tüzel kişilerin sona ermesi ya kendiliğinden ya da bir kararla gerçekleşir. Derneğin kendiliğinden sona ermesi hâlinde, bunun için ayrıca bir karara veya işleme gerek yoktur. Kararla sona ermenin ilk görünümü ise, genel kurul kararıdır. İkinci olarak, dernekler mahkeme kararıyla da sona erebilirler. İnceleme kapsamında önce derneğin sona ermesi hakkında genel bilgiler verildikten sonra, mahkeme kararıyla sona ermeye ilişkin terimlerden söz edilmiştir. Çalışmanın devamında ise, mahkeme kararıyla sona ermenin şartları açıklanmıştır. Bunlar, sona erme sebeplerinden birinin varlığı, istemde bulunulması ve mahkeme kararıdır. Sona erme sebeplerinden derneğin amacının kanuna veya ahlâka aykırı hâle gelmesi uygulama bakımından özellikle önem arz etmektedir. Zira, Yargıtay, bu sebeple derneğin feshi için kanuna veya ahlâka aykırı birden çok fiilin tespit edilmiş olmasını aramaktadır. İstemde bulunabilecek olanlar ise, cumhuriyet savcısı ile ilgililerdir. Burada sona erme bakımından hangi mahkemenin yetkili ve görevli olduğu ile bu kapsamda alınabilecek önlemler de incelenmiştir. Nihayet, derneğin mahkeme kararıyla sona ermesinin sonuçlarına da değinilmiştir.

\begin{abstract}
Associations are composed of persons with legal personality established for an ideal purpose. The termination of such legal persons shall take place either automatically or by a decision. If the association terminates automatically, there is no need for a separate decision or procedure. The first appearance is the decision of the general meeting. Secondly, associations may end by court order. After providing general information about the termination of the association within the scope of the article, the terminology related to the termination by court order is mentioned. The conditions of termination by court order are explained, as well. These are the existence of one of the reasons for the termination, the request and finally the court order. It is particularly important in practice that the objects of the association to be unlawful or immoral for the termination. For this reason, the Turkish Court of Appeal says that there must be more than one act determined against the law or morality for the termination of the association. Those who may request are interested party and the public prosecutor. The competent court and measures that can be taken are also examined. Finally, the consequences of the association's termination by court decision are also mentioned.
\end{abstract}




\section{GİRIŞ}

Dernekler, en az yedi kişinin kazanç paylaşma dışında belirli ve ortak bir amacı gerçekleştirmek üzere bilgi ve çalışmalarını sürekli olarak birleştirmek suretiyle oluşturdukları kişi topluluklarıdır (TMK m.56/I; DK m.2, b. a). Görüldüğü üzere, derneğin ilk unsuru, kişidir. Derneği oluşturan kişilere ise üye denir. Nitekim, derneğin kurulabilmesi için en az yedi gerçek veya tüzel kişinin bilgi ve çalışmalarını birleştirmesi gerekir. Şüphesiz ki, kurulduktan sonra da derneğe üye olarak katılmak mümkündür ${ }^{1}$.

Derneğin ikinci unsuru amaçtır. Zira, dernek şeklindeki kişi topluluğu belirli ve ortak bir amacı gerçekleştirmek üzere bir araya gelmiş olmalıdır. Hemen belirtilmelidir ki, derneğin amacı hukuka veya ahlâka aykırı olamaz (TMK m.56/II). Ayrıca bunun ideal, yani ekonomik nitelik taşımayan bir amaç olması gerekir ${ }^{2}$. Nihayet, dernek şeklindeki kişi toplulukları aynı zamanda tüzel kişilikle donatılmıştır (TMK m.56/I; DK m.2, b. a, m.9/I). Bu sayede, derneğin, kendisini oluşturan üyelerdeki değişikliklerden etkilenmemesi sağlanmış olur ${ }^{3}$.

Derneklerin kuruluşu bakımından esas itibariyle serbest kuruluş sistemi geçerlidir. Gerçekten de, herkes önceden izin almaksızın dernek kurma hakkına sahiptir (AY m.33/I). Bununla beraber, TMK m.59/I gereğince derneğin tüzel kişilik kazanması için kanunda sayılan belgelerin yetkili mercie verilmesi de gerekmektedir ${ }^{4}$.

Aşağıda önce sırasıyla derneğin sona erme sebepleri hakkında açıklamada bulunulmuştur. Devamında ise, çalışmanın konusu çerçevesinde tüzel kişilik kazanmış bulunan derneğin mahkeme kararıyla sona ermesi incelenmiştir.

\section{DERNEĞIIN SONA ERMESI}

Derneğin tüzel kişilik kazanması gibi, bunu kaybetmesi, yani sona ermesi de mümkündür. Derneklerin sona erme sebepleri daha ziyade 4721 sayılı Türk Medenî Kanunu'nda düzenlenmektedir. Derneği sona erdiren sebepler esas itibariyle ikiye ayrilabilir. Söz konusu sebeplerden ilki, derneğin kendiliğinden sona ermesidir. Bunun yerine, doktrinde infisah, dağılma gibi deyimler de kullanılmaktadır ${ }^{5}$. Diğer sona erme sebeplerinde ise dernek ya yetkili bir organ ya da makamın kararı ile ortadan kalkar. Derneklerin tüzel kişiliğine bu şekilde bir kararla son

\footnotetext{
1 ÖZSUNAY, Ergun: Medenî Hukukumuzda Tüzel Kişiler, Tüzel Kişilerin Genel Teorisi - Dernekler -Vakıflar, 3. Baskı, İstanbul 1974, s.77; HATEMİ, Hüseyin/KALKAN OĞUZTÜRK, Burcu: Kişiler Hukuku (Gerçek Kişiler Tüzel Kişiler), İstanbul 2014, s.87; ZEYTİN, Zafer/ERGÜN, Ömer: Türk Medenî Hukuku, 4. Baskı, Ankara 2018, s.113; SEROZAN, Rona: Medenî Hukuk, Genel Bölüm, Kişiler Hukuku, İstanbul 2011, s.448; İNAN, Ali Naim: Medenî Hukuk, 2. Baskı, Ankara 2005, s.153; KILIÇOĞLU, Ahmet M.: Medenî Hukuk Temel Bilgiler, 7. Baskı, Ankara 2018, s.230; OĞUZMAN, M. Kemal/SELİÇI, Özer/OKTAY-ÖZDEMİR, Saibe: Kişiler Hukuku (Gerçek ve Tüzel Kişiler), 18. Baskı, İstanbul 2019, s.330; DURAL, Mustafa/ÖĞÜZ, Tufan: Türk Özel Hukuku, C.II, Kişiler Hukuku, 10. Bask1, İstanbul 2010, s.254; AKINTÜRK, Turgut/ATEŞ, Derya: Medenî Hukuk, 25. Bask1, 2019, s.197; AKİPEK Jale G./AKINTÜRK, Turgut/ATEŞ KARAMAN, Derya: Türk Medenî Hukuku, Başlangıç Hükümleri Kişiler Hukuku, C.1, 9. Baskı, İstanbul 2012, s.565 vd.; ÖZTAN, Bilge: Medenî Hukukun Temel Kavramları, 21. Bask1, Ankara 2006, s.340; HELVACI, Serap/ERLÜLE, Fulya: Medenî Hukuk, 2. Bask1, İstanbul 2011, s.105; BOZKURT, Enver: Hukukun Temel Kavramları, 13. Bask1, Ankara 2018, s.195; SAKA, Zafer: Dernekler Hukuku, İstanbul 2010, s.2-3.

2 ÖZSUNAY, s.110 vd.; SEROZAN, s.448; İNAN, s.157-158; DURAL/ÖĞÜZ, s.271; OĞUZMAN/SELİÇİOKTAYÖZDEMİ, s.330; ZEYTIN/ERGÜN, s.113; AKINTÜRK/ATEŞ, s.197; ÖZTAN, s.341; KILIÇOĞLU, s.232-233; HELVACI/ERLÜLE, s.105; ARAT, Serdar: Ehliyetleri Açısından Dernek ve Vakıf Tüzel Kişilikleri (Medenî Hukuk Tüzel Kişilikleri), Yayımlanmamıș Yüksek Lisans Tezi, İstanbul 2007, s.36 vd.

3 OĞUZMAN/SELİÇ̇/OKTAY-ÖZDEMIR, s.330; AKINTÜRK/ATEŞ, s.197; SEROZAN, s.448; DURAL/ÖĞÜZ, s.255; KILIÇOĞLU, s.230; ÖZTAN, s.342; HELVACI/ERLÜLE, s.105; ZEYTIN/ERGÜN, s.115; HGK. T. 17.4.2002, E. 2002/3-163 K. 2002/308 “... Tüzel kişiler (örneğin dernekler) medeni haklardan istifade (hak) ehliyetine sahiptir, bu nedenle taraf ehliyetine de sahiptir. Tüzel kişilerin kişiliği ve bununla medeni haklardan istifade (hak) ehliyeti tüzel kişiliğin nihayet bulması ile sona erer..." (KBIBBB).

${ }^{4}$ DURAL/ÖĞÜZ, s.264; ZEYTİN/ERGÜN, s.117; HATEMİ/KALKAN OĞUZTÜRK, s.91; KILIÇOĞLU, s.232; HELVACI/ERLÜLE, s.107. Derneklerin kuruluşu bakımından normatif sistemin geçerli olduğu hakkında bkz. ZEVKLILER, Aydın/ERTAŞ, Şeref/HAVUTÇU, Ayşe/ACABEY, M. Beşir/GÜRPINAR, Damla, Yeni Medenî Kanuna Göre Medenî Hukuk (Temel Bilgiler), 10. Baskı, Ankara 2018, s.153.

5 TELLIOĞLU, Filinta Rozerin, "Derneğin Mahkeme Kararı İle Sona Ermesi”, DÜAMYOD, 2(3), 2018, s.3; ZEVKLİLER/ERTAŞ/HAVUTÇU/ACABEY/GÜRPINAR, s.186; İNAN, s.168; HATEMİ/KALKAN OĞUZTÜRK, s.100; SEROZAN, s.452; AKINTÜRK/ATEŞ, s.212; OĞUZMAN/SELIÇ்̇/OKTAY-ÖZDEMIR, s.387; DURAL/ÖĞÜZ, s.311; ÖZTAN, s.381; SAKA, s.227; AKIPEK/AKINTÜRK/ATEŞ KARAMAN, s.649.
} 
verilmesine ise doktrinde fesih (dağıtılma) denir ${ }^{6}$.

Kendiliğinden sona erme sebeplerinden biri bulunduğu takdirde, derneğin hak süjesi niteliğini kaybetmesi için herhangi bir karara veya işleme gerek yoktur. Bu takdirde, dernek kendiliğinden kanun hükmü gereği (ipso iure) sona erer. Bununla birlikte, böyle bir durumda her ilgili derneğin kendiliğinden sona erdiğinin tespitini sulh hâkiminden isteyebilir (TMK m.87/II) ${ }^{7}$. Ancak, cumhuriyet savcısı Kanun'da açıkça öngörülmediği için böyle bir davayı açamaz ${ }^{8}$. Yargitay'a göre, tespit davasında husumet derneğin kendisine yöneltilmelidir'. Tüzel kişiliğin kendiliğinden sona ermesi ihtimalinde davanın derneğe yöneltilmesinin çelişkili olduğu düşünülebilir. Çünkü bu durumda taraf ehliyetinin varlığından dahi söz edilemez (HMK m.114/I, b. d). Diğer taraftan, burada davanın derneğe yöneltilmesi onun daha lehine bir yaklaşım tarzıdır. Çünkü, söz konusu dava reddedilirse, derneğin tüzel kişiliğinin sona ermediği tespit edilmiş olur. $\mathrm{Bu}$ amaçla, derneğin tüzel kişiliğini koruduğuna yönelik savunmada bulunmasına imkân tanınmalıdır. Nitekim TMK m.87/II hükmünde açıkça derneğin sona erdiğinin tespitinin istenebileceği belirtilmektedir. Hükümde geçen ifadeden hareketle, buradaki davanın çeşidinin çekişmeli yargı kapsamındaki bir tespit davası olduğu da anlaşılmaktadır (HMK m.106). Üstelik özellikle davacının derneğin üyesi olması durumunda tespit davası için aranan hukukî yarar şartının varlığı da barizdir.

Derneklerin hangi hâllerde kendiliğinden sona ermiş sayılacağı hususu TMK m.87/I hükmünde düzenlenmektedir. Buna göre, amacın gerçekleşmesi veya gerçekleşmesinin imkânsız hâle gelmesi söz konusu sebeplerden biridir (TMK m.87/I, b. 1). Meselâ, dernek 2030 Dünya Kupasının Türkiye'de yapılması amacıyla kurulmuş ve bu kupa Türkiye'de yapılmışsa artık kendiliğinden sona erer. Şayet kuruluş sırasında derneğin tüzügünde devam edeceği süre öngörülmüşse bunun sona ermesi de başka bir işleme gerek olmaksızın tüzel kişinin dağılmasına yol açar. Dernek mülkî amirin kuruluş bildiriminin uygunluğunu yazılı olarak kendisine bildirmesinden itibaren altı ay içinde ilk genel kurul toplantısı yapmamış ve zorunlu organların oluşturmamışsa bu da bir kendiliğinden sona erme sebebidir (TMK m.87/I, b. 2, m.62) ${ }^{10}$. Derneğin borç ödemeden acze düşmüş olması da buraya dâhildir (TMK m.87/I, b. 3). Bunun için, derneğin borçlarını ödeyemeyecek durumda olması gerekir ${ }^{11}$. Meselâ, derneğe karşı başlatılan icra takipleri sonucunda alacaklılara aciz belgesi verilirse durum böyledir. Dernek tüzüğü gereğince yönetim kurulunun oluşturulmasının imkânsız hâle gelmesi de kendiliğinden sona ermeye sebep olur (TMK m.87/I, b. 4). Meselâ, dernek üye sayıs1 dörde düşerse artık yönetim kurulu oluşturulamaz (TMK m.84/I). Ancak, bunun için yönetim kurulunun oluşturulamaması

\footnotetext{
${ }^{6}$ AKINTÜRK/ATEŞ, s.212; TELLİOĞLU, s.3; ZEVKLİLER/ERTAŞ/HAVUTÇU/ACABEY/GÜRPINAR, s.187; HATEMİ/KALKAN OĞUZTÜRK, s.100; SEROZAN, s.452; KILIÇOĞLU, s.233; İNAN, s.169; AKİPEK/AKINTÜRK/ATEŞ KARAMAN, s.653; SAKA, s.235.

${ }^{7}$ HATEMI/KALKAN OĞUZTÜRK, s.101; ÖZTAN, s.381; ZEYTIN/ERGÜN, s.135; AKINTÜRK/ATEŞ, s.212; ZEVKLILER/ERTAŞ/HAVUTÇU/ACABEY/GÜRPINAR, s.186; İNAN, s.168; SAKA, s.227-228; 2. HD. T. 4.2.2009, E. 2007/16488 K. 2009/1441 (KBİBB); 2. HD. T. 6.12.2007, E. 2007/16492 K. 2007/17085 (KBİBB); 2. HD. T. 12.6.2006, E. 2006/2649 K. 2006/9301 (KBİBB); 18. HD. T. 12.1.2015, E. 2014/20992 K. 2015/34 (KBIBBB); 2. HD. T. 27.6.2002, E. 2002/7549 K. 2002/8557 (KBİBB).

8 18. HD. T. 17.11.2015, E. 2015/17877 K. 2015/16618 “...Yukarıda gösterilen yasal düzenlemeler ve yapılan açıklamalar dikkate alındığında Cumhuriyet Savcısının özel hukuk alanında dava açma hak ve yetkisinin sınırlı olduğu, bu yetkinin sınırının yine yetkiyi veren kanun ile düzenlendiği anlaşılmaktadır. Kanununun açıkça yetki vermediği bir konuda Cumhuriyet Savcısının davaname ile dava açarak derneğin feshini istemesi durumunda, Cumhuriyet Savcısının kaynağını Anayasa'dan ve kanunlardan almayan bir devlet yetkisini kullanmış olacă̆ı, diğer bir anlatımla bu şekilde dava açmakta yetkisiz olduğu da her türlü duraksamadan uzaktır. Hâl böyle olunca, davacı Cumhuriyet Savcllı̆ııın dava açma hakkı bulunmadığı gözetilerek davanın reddine karar verilmesi gerekirken, işin esasına girilerek davanın kabulüne karar verilmesi doğru görülmemiştir...” (KBİBB).

9 7. HD. T. 4.2.2013, E. 2012/8871 K. 2013/723 “...Sonradan oluşan dağılma hâlinin tespiti davasında husumetin kuruculara değil doğrudan derneğe yöneltilmesi ve taraf teşkilinin bu şekilde sağlanması gerekir...” (KBİBB). Farklı yönde bir karar için bkz. 2. HD. T. 24.2.2005, E. 2004/16831 K. 2005/2728 “... Dava Türk Medenî Kanununun 87/2. maddesine dayalıdır. Davada geçici yönetim kuruluna temsil yetkisi verilmediğinden tüm yönetim kurulunun davalı gösterilmesi gerekirken..." (KBİBB).

10 2. HD. T. 12.6.2007, E. 2007/2649 K. 2007/9301 (KBİBB); 2. HD. T. 14.6.2007, E. 2007/8968 K. 2007/10079 “... Dosyaya sunulan belgelerden davalı dernek, ilk genel kurul toplantısını, yasada belirlenen altı aylı süre içinde yapmış ve zorunlu organlarını oluşturmuştur. Genel kurul sonuçlarına ilişsin bildirimin, Dernekler İl Müdürlüğüne, genel kurulu izleyen 30 gün içinde verilmemiş olması, cezai yaptırımı gerektiren bir husus olup, derneğin kendiliğinden dă̆ıldı̆̆ının tespitini gerektirmez...” (KBİBB); 2. HD. T. 22.1.2004, E. 2004/32 K. 2004/736 (KBİBB).

11 7. HD. T. 17.9.2009, E. 2009/3512 K. 2009/3725 “... Aciz hâlinden söz edilebilmesi için bu alacă̆ın tahsili yönünde yürütülmüş yasal takiplerin ( icra takibi v.s.) sonuçsuz kalması gerekmektedir. Dosya içeriğine göre davalı derneğe karşı giriş̧ilmiş bir icra takibinin varlı̆̆ı söz konusu değildir. Derneğin 2.444 TL borcunun olması onun acze düştüğü
} anlamına gelmez..." (KBİBB). 
süreklilik göstermelidir. Nihayet, olağan genel kurul toplantısının iki defa üst üste yapılamamasında da durum böyledir (TMK m.87/I, b. 5) ${ }^{12}$. Gerçekten de, olağan genel kurul toplantısı, TMK m.78/II'de öngörülen toplant1 yeter sayısı bulunmadığ1 için üst üste iki defa yapılamazsa derneğin sona erdiğinin tespiti istenebilir ${ }^{13}$.

Derneğin kararla sona erme hâlinin ilk görünüm şekli, derneğin yetkili organının kararı ile gerçekleşir. Bu konuda karar verme yetkisi dernek genel kuruluna aittir (TMK m.88). Söz konusu yetki, hiçbir şekilde başka bir organ tarafından kullanılamaz (TMK m.81). Derneği sona erdirme kararı için toplantı yeter sayısı, katılma hakkı bulunan üyelerin üçte ikisidir. Ancak, ilk toplantıda toplantı yeter sayısı sağlanamazsa, ikinci toplantıda bu oranda katılım aranmaz. Bu takdirde, katılanların sayısının, yönetim ve denetleme kurulları üye tam sayılarının toplamının iki katından az olmaması yeterlidir (TMK m.78/II). Genel kurulun derneği sona erdirmesi için karar yeter sayısı ise, toplantıya katılan üyelerin üçte iki çoğunluğudur (TMK m.81, c.2). Bununla beraber, dernek tüzüğünde toplantı veya karar yeter sayısı için daha ağır oranlar öngörülebilir. Nihayet, derneğin genel kurul kararı ile sona ermesi hâlinde bu durum yönetim kurulu tarafından mülkî amire bildirilir (DK m.23, DY. m.92) ${ }^{14}$. Derneğin bir kararla sona ermesinin ikinci görünüm şekli ise, mahkeme kararına dayanır. Bu konu ise, aşağıda ayrıntılı olarak incelenmiştir.

\section{TERMINOLOJI}

Üst başlığından anlaşılacağı üzere TMK m.87'de derneğin sona erme sebepleri düzenlenmektedir. Bu kapsamda, "Mahkeme Kararı İle” şeklindeki başlığı gereğince TMK m.89 derneğin mahkeme kararıyla sona ermesine ilişkindir. Aynı hükmün içeriğinde ise, "derneğin feshi" deyimi tercih edilmektedir. Kanunda olduğu gibi, derneğin mahkeme kararı ile sona ermesi bakımından doktrinde çeşitli deyimler kullanılmaktadır. Meselâ, derneğin temelli olarak kapatılmas ${ }^{15}$ bunlardan biridir. Nitekim, 2908 sayılı eski Dernekler Kanunu'nda da aynı deyim esas alınarak derneğin mahkeme kararı ile sona ermesi düzenlenmekteydi (eDK m.52/I). Keza, derneğin yargı organının kararıyla dağıtılmas ${ }^{16}$ ve feshi ${ }^{17}$ de bunlardan bazılarıdır. 5253 sayılı Dernekler Kanunu'nda da derneğin feshine karar verileceğinden söz edilmektedir (DK m.32, b. n, p). Uygulamada da aynı deyimlerin kullanıldığı görülmektedir ${ }^{18}$.

\section{MAHKEME KARARIYLA SONA ERMENIN ŞARTLARI}

\section{A) Mahkeme Kararı}

Dernekler, gerçek kişilere nazaran devletin menfaatlerine ve güvenliğine ilişkin konularda daha etkin bir rol üstlenebilirler. Dolayısıyla devletler, kamu düzenini, iç ve dış güvenliği ya da huzuru bozan derneklerin varlıklarını devam ettirmelerine izin vermezler. Böyle amaçlara

\footnotetext{
12 18. HD. T. 3.7.2012 E. 2012/7561 K. 2012/8389 “...Dosya içindeki bilgi ve belgelerin incelenmesinden, davalı derneğin genel kurul toplantısını 31.06.2006 tarihinde yaptığl, derneğin tüzüğ̈̈ne göre iki yılda bir genel kurul toplantısı yapmak zorunda olduğu ve 22.01.2010 tarihinde olağan genel kurul toplantısını yaptığı anlaşlmaktadır. Buna göre TMK'nın 87/5. maddesinde öngörülen ard arda iki genel kurul yapmama olgusunun somut olayda gerçekleşmediği anlaşıldığından, davanın reddine karar verilmesi gerekirken, delillerin değerlendirilmesinde yanılgıya düşülerek yazll şekilde hüküm kurulması doğru değildir...” (KBİBB); 18 HD. T. 26.6.2012, E. 2012/6217 K. 2012/8108 (KBIBBB); 2. HD. T. 10.3.2008, E. 2007/581 K. 2008/2991 (KBİBB).

${ }^{13}$ HATEMI/KALKAN OĞUZTÜRK, s.101-102; TELLİĞLU, s.4 vd.; OĞUZMAN/SELİÇİ/OKTAY-ÖZDEMIR, s.388; AKINTÜRK/ATEŞ, s.212; ZEVKLILER/ERTAŞ/HAVUTÇU/ACABEY/GÜRPINAR, s.186-187; ÖZTAN, s.381-382; KILIÇOĞLU, s.237; ZEYTIN/ERGÜN, s.135; DURAL/ÖĞÜZ, s.311-312; AKIPEK/AKINTÜRK/ATEŞ KARAMAN, s.649 vd.; İNAN, s.169; HELVACI/ERLÜLE, s.114; ERGÜN, Ömer: Medenî Hukuk Tüzel Kişilerinin Ehliyet Durumu, İstanbul 2010, s.92 vd.; Saka, s.229 vd.; SALDIRIM, Mustafa: “Cumhuriyet Savcisı'nın Özel Hukukta Dernek ve Sendika Tüzel Kișiliğinin Sona Erdirilmesine İlișkin Görevleri”, TBBD., S.59, 2005, s.369 vd.

${ }^{14}$ EGGER, Andreas: İsviçre Medenî Kanunu Şerhi, Giriş ve Kişinin Hukuku, m.1-89, Çev. Volf Çernis, Ankara 1947, s.145; HATEMİ/KALKAN OĞUZTÜRK, s.99; ZEVKLİLER/ERTAŞ/HAVUTÇU/ACABEY/GÜRPINAR， s.187; AKÜNAL, Teoman: Türk Medenî Hukukunda Tüzel Kişiler, İstanbul 1995, s.106; AKINTÜRK/ATEŞ, s.212; OĞUZMAN/SELİÇİOKTAY-ÖZDEMİR, s.386-387; KILIÇOĞLU, s.234; TELLİOĞLU, s.7; DURAL/ÖĞÜZ, s.313; AKİPEK/AKINTÜRK/ATEŞ KARAMAN， s.653-654; İNAN， s.169; HELVACI/ERLÜLE， s.114; ZEYTIN/ERGÜN, s.136; SAKA, s.235.

${ }^{15}$ OĞUZMAN/SELİÇ்/OKTAY-ÖZDEMIR, s.390.

16 SEROZAN, $\quad$ s.452; $\quad$ AKİPEK/AKINTÜRK/ATEŞ $\quad$ KARAMAN, $\quad$ s.654; ZEVKLIILER/ERTAŞ/HAVUTÇU/ACABEY/GÜRPINAR, s.187; SAKA, s.235.

17 SALDIRIM, s.362; DURAL/ÖĞÜZ, s.313; AKINTÜRK/ATEŞ, s.212; ÖZTAN, s.382; SEROZAN, s.452; KILIÇOĞLU, s.237; ZEYTİN/ERGÜN, s.136.

18 2. HD. T. 7.4.2003, E. 2003/3876 K. 2003/5008 (KBİBB); 18. HD. T. 13.1.2015, E. 2014/21559 K. 2015/35 (KBİBB).
} 
yönelen derneklerin tüzel kişiliği devlet tarafından sona erdirilir. Bu konuda, devlet organlarından yarg1 münhasır yetkilidir. Dernek kurma özgürlüğünün (Vereinsfreiheit) bir sonucu olarak bu husus aynı zamanda anayasal güvence altındadır ${ }^{19}$. Gerçekten de, AY m.33/V'e göre ancak hâkim kanunda öngörülen hâllerde derneğin sona erdirilmesine karar verebilir. Benzer bir düzenleme, TMK m.89'da da bulunmaktadır. Söz konusu hükme göre, mahkeme istem üzerine amacı kanuna veya ahlâka aykırı hâle gelen derneğin feshine karar verir ${ }^{20}$. Mahkemenin yenilik doğuran kararı sayesinde dernek geleceğe etkili (ex nunc) olarak ortadan kalkar ${ }^{21}$.

İdarenin böyle bir yetkisi kural olarak yoktur. Ancak, bir görüşe göre, yabancı dernekler bakımından bu konuda bir istisna söz konusudur ${ }^{22}$. Öncelikle belirtilmelidir ki, yabancı dernekler Dışişleri Bakanlığının görüşü ve İçişleri Bakanlığının izni alınmak suretiyle Türkiye'de faaliyette ve işbirliğinde bulunabilirler. $\mathrm{Bu}$ kapsamda, şube açabilirler, üst kuruluşlar kurabilirler ve kurulmuş üst kuruluşlarda yer alabilirler (TMK m.92/II). Buna ilâveten, DK m.5/II sayesinde, yabancı derneklerin Türkiye'de temsilcilik açmaları da mümkün hâle gelmiştir. Ancak, kendisine izin verilmiş durumdaki yabancı dernek, sonradan millî menfaatlere veya kanuna aykırı faaliyette bulunursa, aynı yol izlenerek İçişleri Bakanlığının izni kaldırılabilir. Böylece, alınan başka bir idarî kararla söz konusu derneğin Türkiye'de faaliyette bulunması yasaklanmış olur. Sonuçta, yabanc1 derneğin alınan idarî bir kararla dağıtılması söz konusudur ${ }^{23}$. Nitekim, DK m.32, g hükmünde doğrudan olmasa da bu konuda göz önünde bulundurulabilecek bir düzenleme vardır. Buna göre, yetkili mercilerin izni olmaksızın yabancı derneklerin Türkiye'de temsilciliklerini veya şubelerini açanlar, faaliyetlerini yürütenler, bunlarla işbirliğinde bulunanlar veya bunları üye kabul edenlere bin Türk Lirası idarî para cezası verilir ve izinsiz açılan şube veya temsilciliğin de kapatılmasina karar verilir.

Kanaatimizce, yabancı dernekler için verilen izin yukarıdaki gerekçelerle kaldırılabilir. Böylece, bu tür derneklerin Türkiye'de faaliyette bulunması yasaklanabilir, şubeleri ya da temsilcilikleri kapatılabilir. Aynı durumun Türkiye'de izinsiz faaliyette bulunan yabancı dernekler bakımından da geçerli olduğu zaten kanunda açıkça öngörülmektedir. Ancak, burada sözü edilen hususlar, yabancı derneğin idarî kararla sona erdiği anlamına gelmez. Başka bir deyişle, Anayasa'da ve kanunda öngörülen ancak mahkeme kararıyla bir derneğin kapatılabileceğine ilişkin düzenlemenin burada bir istisnasından söz edilemez. Aksi takdirde, burada Anayasa'ya aykırı bir kanunî düzenlemenin bulunduğu da kabul edilmelidir.

\section{B) İstemde Bulunulması}

Derneğin feshine ilişkin kimlerin istemde bulunabileceği hususu TMK m.89'da açıkça öngörülmektedir. Buna göre, cumhuriyet savcısı veya ilgililer böyle bir istemde bulunabilir. Görüldüğü üzere söz konusu dava, ilk olarak cumhuriyet savcısı tarafından açılabilir. Ancak, İçtihadı Birleştirme Kararı'nda belirtildiği üzere, derneğin feshi davasında cumhuriyet savcısının davacı sıfatıyla hazır bulunmasına gerek yoktur ${ }^{24}$.

Derneğin feshi davası ilgililer tarafından da açılabilir. Ancak, öncelikle ilgililer kavramından ne anlaşılması gerektiği belirlenmelidir. Korunmaya değer maddî veya manevî menfaati olan herkes derneğin feshi davasını açabilir25. İlk olarak dernek üyeleri buraya dâhildir. Aynı şekilde, dernekle aynı amacı güden diğer bir dernek de ilgili olarak değerlendirilmelidir.

\footnotetext{
${ }^{19}$ Dernek özgürlüğü hakkında ayrıntılı bilgi için bkz. PALANDT, Otto: Bürgerliches Gesetzbuch, Bd. 7, 65. Auf., München 2006, s.23; TUOR, Peter/SCHNYDER, Bernhard/SCHMID, Jörg/RUMO-JUNGO, Alexandra: Das Schweizerische Zivilgesetzbuch, 12. Auf., Zürich-Basel-Genf 2002, S.146; HONSELL, Heinrich/VOGT, Nedim Peter/GEISER, Thomas: Basler Kommentar Zum Schweizerischen Privatrecht, Zivilgesetzbuch II, 2. Auf., Basel 2003, s.433-434; DOĞANOĞLU, Ali Erdem: Türk Anayasa Hukukunda Dernek Özgürlügü̈, Yayımlanmamış Yüksek Lisans Tezi, Ankara 2013, s.179 vd.; YILMAZ, Canan: Uluslararası belgelerde ve Türk Hukukunda dernek özgürlüğü, Yayımlanmamış Yüksek Lisans Tezi, İstanbul 2008, s.21 vd.; CANER, Zehra: Dernek Özgürlügü̈, Yayımlanmamış Yüksek Lisans Tezi, Konya 2016, s.33 vd.; DÜNDAR SEZER, Tijen: "Dernek Kurma Özgürlüğünün İçeriği ve Gelişim Süreci Üzerine Karşılaştırmalı Bir İnceleme”, DEÜSBED, 10(1), 2008, s.6 vd.

20 OĞUZMAN/SELIÇĊ/OKTAY-ÖZDEMİR, s.390; AKINTÜRK/ATEŞ, $\quad$ s.212; $\quad$ KILIÇOĞLU, $\quad$ s.237; DURAL/ÖĞÜZ, s.313; AKİPEK/AKINTÜRK/ATEŞ KARAMAN, s.654.

${ }^{21}$ HONSELL/VOGT/GEISER, s.505; SALDIRIM, s.366, 368.

${ }^{22}$ AKIPEK/AKINTÜRK/ATEŞ KARAMAN, s.658; SAKA, s.242; HELVACI/ERLÜLE, s.114.

${ }^{23}$ AKIPPEK/AKINTÜRK/ATEŞ KARAMAN, s.658; SAKA, s.242.

${ }^{24}$ YİBK. T. 17.1.1974, E. 1971/3 K. 1972/2. Bkz. RG. T. 16.4.1972, S.14161. Aksi yönde bir karar için bkz. 2. HD. T. 25.2.2003, E. 2003/1065 K. 2003/2391 “... Dava cumhuriyet savcısı tarafindan davaname ile açılmıştır. Bu nedenle davanın cumhuriyet savcısı huzur ile görülmesi gerekir...” (KBİBB).

${ }^{25}$ AKÜNAL, s.109; ÖZTAN, s.382; İNAN, s.170; DURAL/ÖĞÜZ, s.314.
} 
Keza, dernek alacaklıları da somut olaya göre derneğin feshini dava edebilirler ${ }^{26}$.

Mülkî amirin ilgililer kapsamında değerlendirilip değerlendirilemeyeceği hususu ise tartışmalıdır. Bir görüşe göre, mülkî amir de derneğin feshine yönelik istemde bulunabilir ${ }^{27}$. Gerçekten de, ilgililer deyimi geniş anlamda ele alınmaya elverişlidir. Böylece, burada cumhuriyet savcısının sayılmış olmasının, mülkî amirin ilgililer kapsamının dışında tutulmasına yol açmadığı düşünülebilir. Ancak, diğer bir görüşe göre, en büyük mülkî amir ilgililer kavramına dâhil edilemez ${ }^{28}$. Zira, kamu menfaatinin temsilcisi olarak istemde bulunma yetkisi idarî amirlere değil, cumhuriyet savcılarına tanınmıştır. Böyle bir durumda, mülkî amir ancak derneğin feshi davasını açması için cumhuriyet savcısına bildirimde bulunabilir. Nitekim, eski Dernekler Kanunu'nda da bu yönde düzenleme bulunmaktaydı (eDK m.10/II, m.50/II). Sonuç olarak, mülkî amir kanunda açıkça sayılmadığı için kanaatimizce de ikinci görüş daha isabetlidir.

\section{C) Mahkeme Kararıyla Sona Erme Sebeplerinden Birinin Varlığı}

Bir derneğin mahkeme kararıyla sona ermesi için sebebin kanunda aç1kça öngörülmüş olması gerekir. Gerçekten de, dernek özgürlüğünün bir sonucu olarak Kanun'da sayılan sona erme sebepleri tahdidî nitelikte olup, genişletici bir yoruma tâbi tutulamaz ${ }^{29}$.

\section{Derneğin Amacının Kanuna veya Ahlâka Aykırı Hâle Gelmesi}

Derneğin amacı kanuna veya ahlâka aykırı hâle gelirse bu bir kapatma sebebidir. Ancak, burada öncelikle amacın başlangıçta $\mathrm{m} 1$ yoksa daha sonra $\mathrm{m}$ เ kanuna veya ahlâka aykırı olduğunun belirlenmesi gerekir. Zira, derneğin amacı başlangıçta hukuka veya ahlâka aykırı ise, bu durum onun tüzel kişilik kazanmasına engel oluşturur (TMK m.47/II, m.56/II; DK m.30, b. b) ${ }^{30}$. Tüzel kişiliğin kazanılamadığı hâllerde dernek kurulmasına yönelik işlem baştan itibaren geçersizdir, yani dernek hak ehliyetini kazanamamıştır. Böyle bir durumda derneğin tüzel kişilik kazanamamış olması ancak bir tespit davasına konu edilebilir ${ }^{31}$.

Kanuna veya ahlâka aykırıllı̆ın anlamının belirlenmesi bakımından borçlar hukukundaki kurallardan kıyasen de olsa yararlanılabilir (TMK m.5). Dolayısıyla amacın hukuka aykırı olmasından maksat, tüzel kişinin amacının emredici hukuk kurallarına, kamu düzenine ve kişilik haklarına aykırı olmasıdır. Derneğin amacının hukuka aykırı olup olmadığı belirlenirken göz önünde bulundurulması gereken ise dernek tüzügünün içeriğidir. Keza, derneğin amacına yönelik olarak gerçekleştireceği çalışma biçimleri ve faaliyetlerinin de amacın hukuka aykırılığının tespitinde değerlendirmeye tâbi tutulması gerektiği belirtilmektedir. Aynı şekilde, amaca ulaşmak için başvurulacak araçların hukuka veya ahlâka aykırı olması da dernek tüzel kişiliğinin kazanılmasina engeldir ${ }^{32}$.

Ahlâka aykırılıktan maksat, derneğin amacının toplumda yerleşik ahlâkî kurallara aykırı

\footnotetext{
${ }^{26}$ ÇAĞIRGAN, Senar: Derneklerin Hak ve Fiil Ehliyeti, Yayımlanmamış Yüksek Lisans Tezi, İzmir 2006, S.191.

27 VELIDEDEOĞLU, Hifzı Veldet/ATAAY, Aytekin: Türk Cemiyetler Hukuku, İstanbul 1956, s.107; Saka, s.240.

${ }^{28}$ AKIPEK/AKINTÜRK/ATEŞ KARAMAN, s.657.

${ }^{29}$ SALDIRIM, s.362; TELLIOĞLLU, s.8; HGK. T. 4.3.2015, E. 2013/7-1732 K. 2015/897 “... Yukarlda belirtilen mevzuat incelenmesinde; hukuk sistemimizde dernek kurma hakk bakımından özgürlük sisteminin benimsendiği anlaşılmıştır. Bu nedenle öngörülen istisnaî hâller dışında yeni kapatma nedenleri oluşturulamayacă̆ gibi, isim benzerliğinin kapatma nedenleri arasında düzenlenmemesi nedeniyle Anayasanın dernek kurma özgürlüğ̈̈ ilkesine aykırı olarak kapatma nedeni olarak kabul edilmesi mümkün değildir... Somut uyuşmazlıkta davacı vekili, müvekkilinin isminin Mersin Toroslar İlçe ve Beldeleri Pazarcıları Koruma ve Dayanışma Derneği olduğunu, daha sonra kurulan ve ayn ilçede faaliyet gösteren davalı Toroslar Beldesi Pazarcıları Koruma ve Dayanışma Derneği'nin isim benzerliği ve isminde ayırıcı unsur bulunmadiğını gerekçe göstererek kapatılmasını istemiş ise de; taraf dernek tüzükleri incelendiğinde, derneklerin isimlerinin aynı olmadığ Dernekler Müdürlüğ̈̈ne verdikleri, Valilikçe yapılan araştırma sonunda mevzuata aykırılık görülmediğinden derneklerin kurulmalarına izin verildiği anlaşılmaktadır...” (KBİBB); 7. HD. T. 15.7.2008, E. 2008/2176 K. 2008/3185 “... 5253 Sayll Kanunda derneklerin feshiyle ilgili hüküm bulunmamaktadır. Bu kanunun 34. maddesi hükmünde yollama nedeniyle (atıf gereğince) 4721 sayılı TMK'nın dernek feshiyle ilgili hükümlerinin uygulanması zorunlu ve gereklidir..." (KBİBB).

30 ABLUM, Bahattin/SÜRBAHAN, Sadrettin: Açıklamalı Dernekler Kanunu, Ankara 1973, s.47; DURAL/ÖĞÜZ, s.273.

${ }^{31}$ BGE 112 II 6; BGE 108 II 403; HONSELL/VOGT/GEISER, s.504; BENLİ, Fatma: Derneklerin sona erme nedenleri, Yayımlanmamış Yüksek Lisans Tezi, İstanbul 2014, s.99; ÇAĞIRGAN, s.190-191; HATEMİ/KALKAN OĞUZTÜRK, s.102; ZEVKLİLER/ERTAŞ/HAVUTÇU/ACABEY/GÜRPINAR, s.161; ZEYTIN/ERGÜN, s.134; SALDIRIM, s.365.

${ }^{32}$ HONSELL/VOGT/GEISER, s.504; DURAL/ÖĞÜZ, s.227.
} 
olmasıdır. Başka bir deyişle, burada ahlâka aykırılık genel ahlâka aykırılı̆̆ ifade eder ${ }^{33}$.

Yargıtay'a göre, lezbiyen, gey, biseksüel, travesti ve transeksüel kişiler arasında dayanışma sağlamak amacıyla kurulan derneğin kapatılmasına ilişkin dava reddedilmelidir ${ }^{34}$. Zira, kanunda buna ilişkin bir yasak bulunmamaktadır. Söz konusu davada her ne kadar derneğin feshi ele alınmışsa da, burada aslında derneğin amacının başlangıçta hukuka veya ahlâka aykırı olup olmadığının belirlenmesi söz konusudur.

Başlangıçta amacı hukuka veya ahlâka aykırı olmayan bir derneğin sonradan buna yönelmesi de mümkündür. Amacı sonradan hukuka veya ahlâka aykırı hâle gelen dernek tüzel kişiliği, istem üzerine mahkeme tarafından sona erdirilir. Demek ki, derneğin feshine karar verilmesi için amacın kurulduktan sonraki süreçte hukuka veya ahlâka aykırı hâle gelmiş olması gerekir $^{35}$. Aynı şekilde, tüzel kişilik kazandıktan sonra amacı kazanç paylaşmaya dönüşen derneğin de mahkeme kararıyla sona erdirilmesi mümkündür ${ }^{36}$.

Mahkeme kararıyla sona erme bakımından göz önünde bulundurulması gereken, derneğin fiilen izlemekte olduğu amacın kanuna veya ahlâka aykırı hâle gelip gelmediği hususudur. Bu bakımdan, tüzük değişikliğinin yapılmış olmasına ise gerek yoktur ${ }^{37}$.

Derneğin amacının ne zaman kanuna veya ahlâka aykırı hâle gelmiş sayılacağı burada cevaplanması gereken bir sorudur. Bir derneğin tüzüğüne aykırı tek bir faaliyette bulunmuş olması, genellikle feshi için yeterli sayılmaz. Bu konuda açık bir düzenleme olmasa da, kanundaki derneklere ilişkin hükümlerin genel yapısından hareketle bu sonuca ulaşmak mümkündür. Keza, derneğin amacı ve konusu dışında bir faaliyette bulunmuş olması da mahkeme kararıyla feshedilmesine yol açmaz ${ }^{38}$.

Bir derneğin kanuna veya ahlâka aykırı faaliyetlerinin tekrarlanarak sürekli bir hâl almasında ise durum farklıdır. Zira, derneğin bu şekilde süreklilik kazanan faaliyetleri onun amacının aslında fiilen değişmiş olduğunu gösterir. Meselâ, yoksullara yardım etmek üzere kurulan bir derneğin ırk veya mezhep esasına göre yardımda bulunması ya da aynı konularda ayrımcıllğı ve bölücülüğü içeren broşür ve kitaplar yayımlaması, konferanslar düzenlemesi kanuna aykırı faaliyetlerdir. Keza modern resim sanatını yaymak amacıyla kurulan bir derneğin sürekli şekilde müstehcen ve sanat değeri bulunmayan resimlerden oluşan sergiler açması, bunları dağıtması, değişen amacını gerçekleştirmek üzere söz konusu tarzda reklam broşürleri ya da filmler hazırlatması ahlâka aykırı faaliyette bulunduğunu gösterii ${ }^{39}$.

Yargitay tarafından da süreklilik unsurunun arandığı anlaşılmaktadır ${ }^{40}$. Yüksek Mahkeme'ye göre, suça konu tek bir fiil, davalı derneğin bu suçun kaynağını oluşturduğu anlamına gelmez. Bir derneğin feshedilebilmesi için onun suç sayılan eylemlerin kaynağı hâline geldiğinin, süregelen ve birden fazla eylemin varlığının tespit edilmiş olması gerekir. Sadece bu durumda dernek üyelerinin gerçek amaçlarının dernek faaliyeti yürütmek değil de, dernek adı altında suç işlemeye veya ahlâka aykırı çalışmalar yapmaya yönelik kanunî zemin hazırlamak olduğundan söz edilebilir. Karara konu olaylarda ise, feshi istenen davalı dernekte yapılan aramada kumar oynandığ anlaşılmıştır. Bu gerekçe ile bir olayda dernek başkanı, diğerinde ise başkan yardımcısı hakkında kumar oynanması için yer ve imkân sağlamak suçundan (TCK. m.228) dolayı dava açılmış ve sonuçta suçun işlendiği sabit olduğu için sanığın cezalandırılmasına karar verilmiştir ${ }^{41}$.

\footnotetext{
${ }^{33}$ EGGER, s.22; HONSELL/VOGT/GEISER, s.505; DURAL/ÖĞÜZ, s.227.

34 7. HD. T. 25.11.2008, E. 2008/4109 K. 2008/5196 (KBIBBB).

35 OĞUZMAN/SELIÇİ/OKTAY-ÖZDEMİR， s.390; DURAL/ÖĞÜZ， s.314; AKİPEK/AKINTÜRK/ATEŞ KARAMAN, s.654; SALDIRIM, s.365.

${ }^{36}$ HONSELL/VOGT/GEISER, s.504.

37 OĞUZMAN/SELIÇİ/OKTAY-ÖZDEMIR, s.390; TELLİOĞLU, s.9; SALDIRIM, s.365-366.

${ }^{38}$ EGGER, s.147; HONSELL/VOGT/GEISER, s.504; SALDIRIM, s.362; AKIPEK/AKINTÜRK/ATEŞ KARAMAN, s.656.

${ }^{39}$ AKIPEK/AKINTÜRK/ATEŞ KARAMAN, s.656; TELLIOĞLU, s.9; SAKA, s.240.

40 18. HD. T. 10.7.2012, E. 2012/6816 K. 2012/8976 (KBIBBB); 18. HD. T. 13.1.2015, E. 2014/21559 K. 2015/35 (KBİBB).

${ }^{41}$ 18. HD. T. 13.1.2015, E. 2014/21559 K. 2015/35 “... Dosyadaki bilgi ve belgeler ile suça konu tek eylem daval derneğin bu suçun kaynağı hâline geldiğini göstermeye yeterli nitelikte kabul edilemez. Nitekim, Anayasa Mahkemesi de benzer hüküm taşıyan, Siyasi Partiler Yasasının 103. maddesindeki "... kanunsuz siyasî faaliyetlerin mihrakı olmayı suçun kesif şekilde işlenmesi, birden fazla mahkumiyet, ..." şeklinde yorumlamıştır. (Anayasa Mahkemesi'nin 14.7.1993 tarihli, 92/1-93/1 sayılı kararı) Açıklanan bu olgular gözetildiğinde davalı derneğin kapatılma istemine dair davanın
} 
Kanunda amacın kanuna veya ahlâka aykırı hâle gelmesi bakımından açıkça süreklilik unsuru öngörülmemiştir. Bununla beraber, derneğin kendi sürekliliği göz önünde bulundurulunca böyle bir unsurun aranması makûl karşılanabilir. Zira, dernek özgürlüğünün temelinde derneklerin varlık güvencesine sahip olması yer alır. Ancak derneklere tanınan söz konusu güvence, hukuka uygun bir amaca ulaşmak için hukuka uygun faaliyetlerde bulunan derneklerin korunması bakımından geçerlidir ${ }^{42}$. Dolayısıyla Yargıtay'ın yukarıdaki yaklaşımı isabetli değildir. Çünkü, gerekçede belirtildiğinin aksine böyle bir durumda dernek üyelerinin "bireysel" nitelikte suç işlediklerinden söz edilemez. Aksine, dernek aslında kumar, fuhuş, uyuşturucu satışı gibi kanuna veya ahlâka aykırı faaliyetlerin merkezi hâline dönüşmüşse burada artık derneğin feshine karar verilmelidir. Dernek yöneticisinin böyle bir suçtan dolayı ceza almış olması da bunun en önemli delilidir. Kumar oynanması için yer ve imkân sağlama suçunun işlenmesi için burada kullanılan mekân derneğe aittir, bunu sağlayan da bizzat dernek başkanı ya da yardımcısıdır. Burada artık aynı suçtan dolayı ikinci bir aramanın yapılmasının ve bunun sonucunda başka bir üyenin de ceza almasının beklenmesi anlamsız olur. Aynı durum, hukuka uygun amaçlarla kurulmuş derneğin sonradan örgüt faaliyetlerinde kullanılması misalinde de karşımıza çıkar. Gerçekten de, yöneticilerin bazıları tarafından dernek merkezinin terör örgütüne yardım ve yataklıkta kullanılması sonucunda suçu işleyenler hakkında ceza verildiğini düşünelim.Burada da aynı suçtan dolayı dernek yöneticileri hakkında tekrar ceza verilmesi beklenmemelidir. Aksine bir yaklaşım ise, sadece kanuna veya ahlâka aykırı faaliyetlerde aracı olarak kullanılan derneklerin önünün açılmasına yardımcı olur. Diğer taraftan, belirtilmelidir ki, dernek hakkındaki tek bir ihbar ya da tek bir polis tutanağı vs. ise derneğin kapatılmasına gerekçe olamaz. Burada derneğin amacının sürekli biçimde kanuna veya ahlâka aykırı hâle geldiğinden söz edilemez. Aynı şekilde, dernek yöneticisinin dernek faaliyetlerini ilgilendirmeyen bir suçtan dolayı ceza almış olması da derneğin kapatılmasına yol açmaz. Meselâ, dernek yöneticisinin hırsızlık suçundan ceza almış olmasında durum böyledir.

Nihayet, kanuna aykırılıktan dolayı derneğin sona erdirilmesi bakımından 5072 sayılı Dernek ve Vakıfların Kamu Kurum ve Kuruluşları ile İlişkilerine Dair Kanun'daki düzenlemeden de söz edilmelidir. 5072 sayılı Kanun m.3/III gereğince, dernek tüzüğü bu kanuna aykırı olan veya bu kanuna aykırı işlemleri tespit edilen dernekler genel hükümlere göre kapatılır. Kapatılan dernek malları hazineye intikal eder. Bu takdirde, dernek yöneticileri eylemleri başka bir suç oluşturmadığ 1 takdirde, üç aydan bir yıla kadar hapis cezası ile cezalandırılır. Benzer bir düzenleme, aynı Kanun'da geçici m.1/II'de öngörülmektedir. Buna göre, dernek tüzügünü altı ay içinde bu Kanuna uygun hâle getirmeyen veya söz konusu Kanuna aykırı işlemleri tespit edilen dernekler yine genel hükümlere göre kapatılır. Burada da dernek mallarının akıbeti ile dernek yöneticilerinin cezaî sorumluluğu, aynı kanunun 3 . maddesine uygun şekilde düzenlenmektedir ${ }^{43}$.

\section{Kuruluştaki Kanuna Aykırılıkların veya Eksikliklerin Giderilememesi}

Dernekler kuruluş bildirimini, dernek tüzüğünü ve gerekli diğer belgeleri yerleşim yerinin bulunduğu yerin en büyük mülkî amirine verdikleri anda tüzel kişilik kazanırlar. Bunun ardından, kuruluş bildirimi ve belgelerin doğruluğu ile dernek tüzüğü en büyük mülkî amir tarafından altmış gün içinde dosya üzerinden incelenir (TMK m.60/I). Görüldüğü üzere dernek, tüzel kişiliğini söz konusu incelemeden önce kazanır, yeter ki amacı başlangıçta hukuka veya ahlâka aykırı olmasın. İnceleme sonucuna göre ise, geçerli bir şekilde kurulmuş bulunan derneğin feshi söz konusu olmaktadir ${ }^{44}$.

Kuruluş bildiriminin, tüzüğün ve kurucuların hukukî durumlarının idare tarafından incelenmesinde kanuna aykırılık veya noksanlık tespit edilmiş olabilir. Bu takdirde, bunların tamamlanması veya giderilmesi kuruculardan istenir. Aykırılık veya noksanlık, bu istemin tebliğinden itibaren otuz gün içinde giderilirse, söz konusu durum derneğe yazıyla bildirilir ve dernek de kütüğe kaydedilir (TMK m.60/III; DK m.17). Ancak, aynı sürede belirtilen noksanlık tamamlanmaz ve kanuna aykırılık giderilmezse, en büyük mülkî amir durumu cumhuriyet

reddine karar verilmesi gerekirken, yerinde olmayan gerekçe ile kabulüne karar verilmesi doğru görülmemiştir..." (KBİBB); 18. HD. T. 10.7.2012, E. 2012/6816 K. 2012/8976 (KBİBB).

${ }^{42}$ DOĞANOĞLU, s.254.

${ }^{43}$ AKIPEK/AKINTÜRK/ATEŞ KARAMAN, s.657-657.

$44 \quad$ OĞUZMAN/SELIÇ்̇/OKTAY-ÖZDEMİR, s.297; $\quad$ ÖZTAN, $\quad$ s.383; $\quad$ KILIÇOĞLU, $\quad$ s.237; AKİPEK/AKINTÜRK/ATEŞ KARAMAN, s.654-655; ZEVKLİLER/ERTAŞ/HAVUTÇU/ACABEY/GÜRPINAR, s.187; SALDIRIM, s.363; TELLİĞLUU, s.8; SAKA, s.241. 
savcısına bildirir. Mülkî amirin bildirimi üzerine cumhuriyet savcısı tarafından derneğin feshi davası açılır ve sonuçta dernek yine mahkeme kararı ile feshedilir (TMK m.60/II) ${ }^{45}$. Ancak, derneğin feshedilebilmesi için kanuna aykırılıkların veya eksikliklerin giderilmesine yönelik ihtarda bulunulmuş olmalıdır. Aksi takdirde, derneğin feshine karar verilemez ${ }^{46}$.

\section{Zorunlu Organların Oluşturulamaması veya Olağan Genel Kurul Toplantısının}

Tüzükte Belirtilen Zamanda Yapılmamas1

Derneklerin zorunlu organları üç tanedir. Bunlar, genel kurul, yönetim kurulu ve denetim kuruludur (TMK m.72/I). Söz konusu organlardan genel kurulun ilk toplantısı (TMK m.62) bir kenara bırakılırsa, biri olağan diğeri olağanüstü olmak üzere iki tür genel kurul toplantısı vardır. Olağanüstü genel kurul toplantısı bakımından herhangi bir zaman sinırlaması yoktur. Olağan genel kurul toplantısı ise, dernek tüzüğünde belirlenen zamanlarda ve yönetim kurulunun çağrısı üzerine yapılır (TMK m.74/I; DY. m.13/I, b. a). Ancak, tüzükte herhangi bir hüküm öngörülmemiş olsa bile, olağan genel kurul toplantısının en geç üç yılda bir defa yapılması zorunludur (TMK m.74/II, DY. m.13/II) ${ }^{47}$.

Zorunlu organların oluşturulmamış veya olağan genel kurul toplantısının zamanında yapılmamış olmasının derneğin tüzel kişiliğine etkisi 2908 sayılı eski Dernekler Kanunu'nda açıkça düzenlenmekteydi. Buna göre, dernek merkezinin bulunduğu yerin en büyük mülki amirinin derneğe yapacağı yazılı ihtara rağmen üç ay içinde bu zorunluluklar yerine getirilmezse, derneğin feshine karar verilebilirdi ${ }^{48}$. Gerçekten de, mülkî amirin yazılı bildirimi üzerine cumhuriyet savcılığının istemde bulunmasıyla asliye hukuk mahkemesi derneğin feshine hükmedebilirdi (eDK m.50/I, b. 2-II). 5253 sayılı Dernekler Kanunu'nda ve 4721 sayılı Türk Medenî Kanunu'nda ise buna benzer açık bir hüküm yer almamaktadır. Ancak, lafzından da anlaşılacağ1 üzere TMK m.74/II emredici bir hükümdür. Dolayısıyla söz konusu hükme aykırılığın müeyyidesinin de derneğin mahkeme kararıyla feshedilmesi olduğu kabul edilebilir ${ }^{49}$.

\section{Dernekler Kanunu'nda Sayılan Bir Suçun Dernek Yöneticisi Tarafından İşlenmesi}

“Ceza Hükümleri” üst başlıklı DK m.32 vd.'nda iki hâl bakımından dernek yöneticilerinin kanunda öngörülen yasaklara uymaması sebebiyle derneğin mahkeme kararıyla feshine karar verileceği düzenlenmektedir. Bunlardan ilki, DK m.32, b. n hükmüdür. Söz konusu düzenleme gereğince, DK m.28'de sayılan kelimeleri izinsiz kullanan ya da DK m.29'da belirtilen yasaklara yazılı olarak uyarılmalarına rağmen aykırı hareket eden, yani bunlara uymamakta 1srar eden dernek yöneticileri yüz günden az olmamak üzere adlî para cezası ile cezalandırılır ve derneğin feshine de karar verilir. Burada sözü edilen DK m.28 gereğince dernek adlarında; Türk, Türkiye, Millî, Cumhuriyet, Atatürk, Mustafa Kemal, şehit, gazi kelimeleri ile bunların baş ve sonlarına getirilen eklerle oluşturulan kelimeler ancak İçişleri Bakanlığının izni ile kullanılabilir. DK m.29 hükmü ise bazı ad ve işaretlerin kullanılmasını yasaklamaktadır. Buna göre dernekler, mevcut veya mahkeme kararıyla kapatılmış ya da feshedilmiş bir siyasî partinin, bir sendikanın yahut da üst kuruluşunun, bir derneğin veya üst kuruluşunun adını, amblemini, rumuzunu, rozetini ve benzeri işaretlerini kullanamaz. Aynı yasak başka bir ülkeye ve daha önce kurulmuş Türk devletlerine ait bayrak, amblem ve flamalar bakımından da geçerlidir ${ }^{50}$.

Diğer düzenleme DK m.32, b. p'de öngörülmektedir. Buna göre, DK m.30, b. b bendine aykırı harekette bulunan dernek yöneticileri, fiilleri daha ağır bir cezayı gerektirmezse bir yıldan üç yıla kadar hapis ve elli günden az olmamak üzere adlî para cezası ile cezalandırılır ve derneğin de kapatılmasına karar verilir. Burada sözü edilen DK m.30, b. b'ye göre ise, Anayasa ve kanunlarda açıkça yasaklanan amaçları veya konusu suç oluşturan fiilleri gerçekleştirmek amaciyla dernek kurulamaz ${ }^{51}$. Aksi takdirde, söz konusu yasak amaçlarla kurulan bir dernek asla

\footnotetext{
45 OĞUZMAN/SELIÇİ/OKTAY-ÖZDEMIR, s.390; AKİPEK/AKINTÜRK/ATEŞ KARAMAN, s.655; SAKA, s.241; 7. HD. T. 15.7.2008, E. 2008/2176 K. 2008/3185 (KBİBB).

46 2. HD. T. 16.41998, E. 2893 K. 4387 (SALDIRIM, s.364, dpn. 11).

${ }^{47}$ SEROZAN, s.449; AKIPPEK/AKINTÜRK/ATEŞ KARAMAN, 602 vd.; HATEMİ/KALKAN OĞUZTÜRK, s.98.

48 2. HD. T. 5.12.195, E. 9780 K. 10257 (GÖNENCAN, Zahit: Derneklerin Türk Hukukundaki Yeri, Ankara 1998, s.199).

${ }^{49}$ DURAL/ÖĞÜZ, s.314; AKİPEK/AKINTÜRK/ATEŞ KARAMAN, s.655.

${ }^{50}$ OĞUZMAN/SELIÇİ/OKTAY-ÖZDEMİR, s.393; TELLİOĞLU, s.10; SAKA, s.241.

${ }^{51}$ OĞUZMAN/SELIÇİ/OKTAY-ÖZDEMIR, s.392-393; SAKA, s.241-242.
} 
tüzel kişilik kazanamaz. Dolayısıyla böyle bir derneğin aslında feshine de ihtiyaç yoktur ${ }^{52}$. Ne var ki, DK m.32 hükmü 2008 tarihli değişiklik ${ }^{53}$ ile tekrar düzenlenmiş olmasına rağmen buradaki sorun giderilememiştir.

\section{YETKILII VE GÖREVLİ MAHKEME}

Derneğin feshi kararını vermeye yetkili mahkeme, dernek merkezinin bulunduğu yerdeki mahkemedir. Görevli mahkeme ise, asliye hukuk mahkemesidir (TMK m.60/II) ${ }^{54}$.

Yargılama usulüne ilişkin Dernekler Kanunu'nda özel bir hüküm bulunmaktadır. Buna göre, Dernekler Kanunu ile ilgili olarak hukuk mahkemelerinde bakılacak davalarda basit yargilama usulü uygulanır (DK m.18/I; HMK m.316 vd.) ${ }^{55}$.

\section{ALINABİLECEK ÖNLEMLER}

Derneğin sona erdirilmesine yönelik dava sırasında mahkeme tarafından gerekli önlemlerin alınabileceği hususu TMK m.89, c. 2'de düzenlenmektedir. Buna göre mahkeme, dava sırasında bütün önlemleri alır. Buna derneği faaliyetten alıkoyma, başka bir deyişle derneğin faaliyetinin yasaklanması da dâhildir. AY m.33/V gereğince, derneğin kapatılmasında olduğu gibi, faaliyetten alıkonulması için de hâkim kararının varlığı şarttır. Benzer bir düzenleme, TMK m.90/III'te öngörülmektedir. Buna göre, dernek faaliyetleri ile ilgili yasak ve sınırlamalara aykırılık hâlinde cumhuriyet savcısının istemi üzerine mahkeme tarafından faaliyetten alıkoyma (men) kararı verilebilir. Kanaatimizce, kanun koyucu bu düzenleme sayesinde derneğin feshi davası açılmamış olsa bile söz konusu önlemin alınmasını mümkün kılmıştır ${ }^{56}$.

Mahkeme, yargılamanın her aşamasında gerekli önlemleri almaya yetkilidir. Derneğin sona erdirilmesinden farklı olarak, bunun için bir istemde bulunma zorunluluğu yoktur. Hâkim, istem üzerine olduğu gibi, re'sen de bütün önlemleri alabilir ${ }^{57}$. Hatta, kanun koyucu burada "alır" diyerek, bu önlemlerin alınıp alınmamasını hâkimin takdirine bırakmamıştır.

Kolluk kuvvetlerinin yetkisi DK m.20'de düzenlenmektedir. Buna göre, kolluk kuvvetleri, kural olarak dernek ve eklentilerine giremez, arama yapamaz ve buradaki eşyaya el koyamaz. Söz konusu kuralın istisnası ise aynı hükümde öngörülmektedir. Buna göre, derneğe girme, burada arama yapma ve buradaki eşyaya el koyma, kural olarak ya kamu düzeninin korunması ya da suç işlenmesinin önlenmesi sebeplerinden birinin varllğ kararının varlığına bağlıdır. Burada sayılan önlemlerin alınması, derneği faaliyetten alıkoyulmasına yol açmamalıdır. Ancak, aynı sebeplerden biri varsa gecikmesinde sakınca bulunan durumlarda mülkî idare amirinin yazılı emriyle de bu önlemler alınabilir. Bu takdirde, mülkî idare amirinin kararı yirmi dört saat içinde görevli hâkimin onayına sunulur. Hâkim, kararını el koymadan itibaren kırk sekiz saat içinde açıklar; aksi hâlde, el koyma kendiliğinden kalkar. Sonuçta hâkim kararı, mülkî idare amiri tarafından dernek yöneticilerine yazıyla duyurulur ${ }^{58}$.

\footnotetext{
${ }^{52}$ AKIPPEK/AKINTÜRK/ATEŞ KARAMAN, s.657. Aksi görüş için bkz. TELLİOĞLU, s.11; ÇAĞIRGAN, s.193194.

${ }^{53}$ RG. T. 8.2.2008, S.26781.

54 HONSELL/VOGT/GEISER, s.505; BALLAR, Suat: Türk Dernekler Hukuku, İstanbul 1987, s.201; AKİPEK/AKINTÜRK/ATEŞ KARAMAN, s.658; 18. HD. T. 26.4.2012, E. 2012/3037 K. 2012/4604 “... Davanın açıldığı ve hükmün verildiği tarihte yürürlükte bulunan 1086 sayıl Hukuk Usulü Muhakemeleri Kanununun 8. maddesinde, sulh mahkemesinin görevli olduğu dava ve işler sayılmış, bunlar arasında derneğin feshine ilişkin davaya yer verilmemiştir. Sulh hukuk mahkemesi dar yetkili mahkeme olup, ancak kanunların kendisini görevlendirdiği dava ve işlere bakabilir. Bunun dişındaki davalarda ise asliye hukuk mahkemesinin görevli olduğu kuşkusuzdur. Görev kamu düzenine ilişkin olup yargılamanın her aşamasında kendiliğinden dikkate alınır. Mahkemece, görevli mahkemenin asliye hukuk mahkemesi olduğu kabul edilerek görevsizlik sebebiyle dava dilekçesinin reddine karar verilmesi gerekirken, açıklanan hukuki olgular göz ardl edilerek esas hakkında karar verilmesi doğru görülmemiştir..." (KBİBB).

55 AKİPEK/AKINTÜRK/ATEŞ KARAMAN, s.658; 7. HD. T. 3.2.2011, E. 2010/5128 K. 2011/612 “...Açıklanan hukuksal olgular birlikte değerlendirildiğinde dernekler ile ilgili hukuk davalarında mahkemelerce duruşma yapılmasl, yargılamanın basit yargılama usulüne göre yürütülerek sonuçlandırılması gerektiği kuşkusuzdur..." (KBİBB); 7. HD. T. 10.12.2009, E. 2009/6386 K. 2009/5848 (KBİBB).

56 Söz konusu düzenleme sayesinde, derneğin sürekli olarak faaliyetleriyle ilgili yasak ve sınırlamalara aykırı davranmasının bir tür müeyyidesinin öngörüldüğ̈̈ görüşü için bkz. AKİPEK/AKINTÜRK/ATEŞ KARAMAN, s.656657.

57 OĞUZMAN/SELİÇİ/OKTAY-ÖZDEMIR, s.390; DURAL/ÖĞÜZ, s.313.

${ }^{58}$ OĞUZMAN/SELIÇİ/OKTAY-ÖZDEMIR, s.385; SALDIRIM, s.367.
} 
Mahkemenin aksine, idarenin derneğe müdahale ederek onu faaliyetten alıkoyma yetkisi bulunmamaktadır. Başka bir deyişle, kolluk müdahalesi derneğin yönetim işlerinin durdurulmasına, yani derneğin yönetimsiz kalmasına yol açmamalıdır. Zira, derneğin faaliyetten alıkoyulması için mahkeme tarafından verilmiş faaliyetten men tarzında bir önlem kararının varlığ şarttır ${ }^{59}$.

\section{DERNEĞİN MAHKEME KARARI İLE SONA ERMESINIIN SONUÇLARI}

Diğer sona erme sebeplerinde olduğu gibi, derneğin mahkeme kararı ile feshedilmesi hâlinde de derneğin asıl ve onursal üyelerinin üyelik sıfatları da artık ortadan kalkar. Aynı şekilde, mahkeme kararıyla kapatılma da derneğin tüzel kişiliğinin sona ermesine yol açar ${ }^{60}$. Ancak, derneğin kişiliği, ehliyeti tasfiye amacıyla sınırlı olmak üzere malvarlığının tasfiyesi aşamasında da devam eder (TMK m.52) ${ }^{61}$.

Derneğin mahkeme kararı ile sona ermesinin iki önemli sonucu daha bulunmaktadır. Bunlar, derneğe ait malvarlığının tasfiyesi ve tasfiyede ortaya çıkan fazlalık varsa bunun özgülenmesi (tahsisi)'dir. Tasfiye usulüne mahkeme tarafından karar verilir. Tasfiye kapsamında önce malvarlığında yer alan kıymetlerin değerlendirilmesi gerekir. Sonra da derneğin alacakları tahsil edilip, borçları ödenir. Böylece, derneğin net malvarlığı tespit edilmiş olur. Borçların ödenmesinden bir değer arta kalırsa, bu da özgülenmenin konusunu oluşturur. Ancak mahkeme kararı ile sona eren derneğin malvarlığının özgülenmesi, TMK m.54'te tüzel kişilere ilişkin genel esastan ayrılır. Keza, söz konusu sonuç, genel kurulu kararı ile feshedilen veya kendiliğinden sona erdiği tespit edilen derneğin durumundan da farklıdır. Zira, genel kurul kararı ile feshetme veya kendiliğinden sona erme hâlinde, derneğin para, mal ve hakları öncelikle tüzügünde belirtilen esaslar çerçevesinde özgülenir. Hâlbuki, mahkeme kararı ile sona eren derneklerde tüzüğe bakılmaz. Bu takdirde, derneğin bütün para, mal ve hakları, mahkeme kararıyla derneğin amacına en yakın ve kapatıldığ 1 tarihte en fazla üyeye sahip derneğe devredilir (DK m.15/I, c. 2; DY. m.89). Burada derneğin kapatılması mahkeme kararı sonucunda olacağ i ç̧in kapatılma tarihinden maksat aslında karar tarihidir. DY. m.89/I, b. b hükmünde ise, dernek malvarlığının kendisine özgüleneceği derneğin kapatılan dernekle aynı ilde olması gerektiğinden söz edilmektedir. Ancak, bu ilâve unsurun kanuna aykırı biçimde yönetmelikte öngörülmüş olması eleştiriye açıktır. Mahkeme kararı ile sona ermesine karar verilen derneklerin tasfiye ve özgüleme işlemleri tamamlandıktan sonra dernekler kütügündeki kayıtları silinir (DK m.15/II; DY. m.90) ${ }^{62}$.

Kapatılması için hakkında soruşturma veya dava açılmış olan bir dernek, genel kurul kararı ile feshine ve buna bağlı olarak dernek mallarının devrine, daha doğrusu özgülenmesine ilişkin bir karar almış olabilir. DK m.15/III gereğince, bu karar, soruşturma ve dava sonuçlanıncaya kadar yürürlüğe konulamaz, dolayısıyla da böyle bir özgüleme işlemi yapılamaz ${ }^{63}$.

\section{SONUÇ}

Dernek kurulmasında olduğu gibi, sona ermesinde de dernek özgürlüğü göz önünde bulundurulmalıdır. $\mathrm{Bu}$ doğrultuda, derneklerin bir defaya mahsus hâller sebebiyle sona erdiği kabul edilemez. Nitekim, kendiliğinden sona erme sebeplerinden biri olan yönetim kurulunun oluşturulmasının imkânsız olmasında bu husus dikkate alınmakta ve böylece imkânsızlığın sürekli olması gerektiği isabetli olarak kabul edilmektedir. Aynı yaklaşım, derneğin mahkeme kararı ile sona ermesi için de geçerli olmalıdır. Bu sebeple, derneğin amacının kanuna veya ahlâka

\footnotetext{
${ }^{59}$ OĞUZMAN/SELİÇ̇̇/OKTAY-ÖZDEMİR, s.385-386.

${ }^{60}$ Dan. 3. D. “... Tüzel kişiliği sona eren dernek adına düzenlenen ihbarnamelerin herhangi bir hukuksal sonuç doğurmayacağı açık olup, dernek kütük kaydının silinmesinden sonra derneğin haklara sahip olması, borçlu kılınması ve temsili olanaklı olmadiğından..." (KBİBB).

${ }^{61}$ AKİPEK/AKINTÜRK/ATEŞ KARAMAN, s.659; HATEMİ/KALKAN OĞUZTÜRK, s.103; SEROZAN, s.452; KILIÇOĞLU, s.227; SAKA, s.242; 1. HD. T. 24.10.2007, E. 2007/8092 K. 2007/10045 “....Bilindiği üzere, Dernekler Türk Medenî Kanunu'nun 56. maddesi gereğince tüzel kişiliğe sahip topluluklardır. Sona eren tüzel kişinin kişiliği, ehliyeti tasfiye amactyla sinırlı olmak üzere tasfiye sırasında da devam edeceği yine Medenî Yasanın 52. maddesi hükmü gereğidir...” (KBİBB); 7. HD. T. 28.10.2010, E. 2010/4274 K. 2010/6213 “...Tüzel kişilik kazanan derneğin ne zaman tüzel kişiliğinin son bulduğu konusunda herhangi bir düzenleme bulunmamaktadır. Ancak, 3. kişiler açısından tüzel kişiliğin sona erdiği tarihin, derneğin tasfiyesinin tamamlanıp dernekler sicilinden terkin edildiği tarih olduğu genel kabul ve uygulamanin sonucudur...” (KBİB).

62 DURAL/ÖĞÜZ, s.315; OĞUZMAN/SELİÇİ/OKTAY-ÖZDEMIR, s.393-394; AKİPEK/AKINTÜRK/ATEŞ KARAMAN, s.659; ÖZTAN, s.383; HELVACI/ERLÜLE, s.115; ZEYTIN/ERGÜN, s.137-138; TELLIOĞLU, s.14; SAKA, s.243-244.

63 OĞUZMAN/SELIÇİ/OKTAY-ÖZDEMİR, s.394; ÖZTAN, s.383; AKİPEK/AKINTÜRK/ATEŞ KARAMAN, s.659; ZEYTIN/ERGÜN, s.138.
} 
aykırı hâle geldiğinden söz edebilmek için de süreklilik unsuru göz önünde bulundurulmalıdır. Böylece, dernek kapsamındaki münferit bir faaliyetten dolayı derneğin kapatılması onun toplum hayatındaki işlevini ortadan kaldırır. Ancak süreklilik unsurundan hareketle, hukuka veya ahlâka aykırı faaliyetlerde paravan olarak kullanılan bir derneğin kapatılmaması da isabetli olmaz. Aksi takdirde, dernekler bu tarz hukuka veya ahlâka aykırı faaliyetlerin gerçekleştirilmesinde yönetici ve üyelere meşru bir zemin sağlar. Hâlbuki, kanun koyucunun dernekler sayesinde gerçekleştirmek istediği amaç bu değildir. Dolayısıyla dernekte kumar oynatıldığı için yöneticisi hem de ceza almış bir derneğin kapatılmaması doğru bir yaklaşım değildir.

\section{KAYNAKÇA}

ABLUM, Bahattin/SÜRBAHAN, Sadrettin: Açıklamalı Dernekler Kanunu, Ankara 1973.

AKINTÜRK, Turgut/ATEŞ, Derya: Medenî Hukuk, 25. Baskı, 2019.

AKİPEK Jale G./AKINTÜRK, Turgut/ATEŞ KARAMAN, Derya: Türk Medenî Hukuku, Başlangıç Hükümleri Kişiler Hukuku, C.1, 9. Baskı, İstanbul 2012.

AKÜNAL, Teoman: Türk Medenî Hukukunda Tüzel Kişiler, İstanbul 1995.

ARAT, Serdar: Ehliyetleri Açısından Dernek ve Vakıf Tüzel Kişilikleri (Medenî Hukuk Tüzel Kişilikleri), Yayımlanmamış Yüksek Lisans Tezi, İstanbul 2007.

BALLAR, Suat: Türk Dernekler Hukuku, İstanbul 1987.

BENLİ, Fatma: Derneklerin sona erme nedenleri, Yayımlanmamış Yüksek Lisans Tezi, İstanbul 2014.

BOZKURT, Enver: Hukukun Temel Kavramları, 13. Bask1, Ankara 2018.

CANER, Zehra: Dernek Özgürlüğü, Yayımlanmamış Yüksek Lisans Tezi, Konya 2016.

ÇAĞIRGAN, Senar: Derneklerin Hak ve Fiil Ehliyeti, Yayımlanmamış Yüksek Lisans Tezi, İzmir 2006.

DOĞANOĞLU, Ali Erdem: Türk Anayasa Hukukunda Dernek Özgürlüğü, Yayımlanmamış Yüksek Lisans Tezi, Ankara 2013.

DURAL, Mustafa/ÖĞÜZ, Tufan: Türk Özel Hukuku, C.II, Kişiler Hukuku, 10. Baskı, İstanbul 2010.

DÜNDAR SEZER, Tijen: "Dernek Kurma Özgürlügünün İçeriği ve Gelişim Süreci Üzerine Karşılaş̧ırmalı Bir İnceleme", DEÜSBED., C.10, S. 1, 2008, s.1-58.

EGGER, Andreas: İsviçre Medenî Kanunu Şerhi, Giriş ve Kişinin Hukuku, m.1-89, Çev. Volf Çernis, Ankara 1947.

ERGÜN, Ömer: Medenî Hukuk Tüzel Kişilerinin Ehliyet Durumu, İstanbul 2010.

GÖNENCAN, Zahit: Derneklerin Türk Hukukundaki Yeri, Ankara 1998.

HATEMİ, Hüseyin/KALKAN OĞUZTÜRK, Burcu: Kişiler Hukuku (Gerçek Kişiler - Tüzel Kişiler), İstanbul 2014.

HELVACI, Serap/ERLÜLE, Fulya: Medenî Hukuk, 2. Baskı, İstanbul 2011.

HONSELL, Heinrich/VOGT, Nedim Peter/GEISER, Thomas: Basler Kommentar Zum Schweizerischen Privatrecht, Zivilgesetzbuch II, 2. Auf., Basel 2003.

İNAN, Ali Naim: Medenî Hukuk, 2. Bask1, Ankara 2005.

KILIÇOĞLU, Ahmet M.: Medenî Hukuk Temel Bilgiler, 7. Baskı, Ankara 2018.

OĞUZMAN, M. Kemal/SELIÇİ, Özer/OKTAY-ÖZDEMİR, Saibe: Kişiler Hukuku (Gerçek ve Tüzel Kişiler), 18. Bask1, İstanbul 2019.

ÖZSUNAY, Ergun: Medenî Hukukumuzda Tüzel Kişiler, Tüzel Kişilerin Genel Teorisi - Dernekler Vakıflar, 3. Baskı, İstanbul 1974.

PALANDT, Otto: Bürgerliches Gesetzbuch, Bd. 7, 65. Auf., München 2006.

SAKA, Zafer: Dernekler Hukuku, İstanbul 2010.

SALDIRIM, Mustafa: “Cumhuriyet Savcısı'nın Özel Hukukta Dernek ve Sendika Tüzel Kişiliğinin Sona Erdirilmesine İlişkin Görevleri”, TBBD., S.59, 2005, s.359-376.

SEROZAN, Rona: Medenî Hukuk, Genel Bölüm, Kişiler Hukuku, İstanbul 2011.

TELLIOĞLU, Filinta Rozerin: "Derneğin Mahkeme Kararı İle Sona Ermesi”, DÜAMYOD., C.2, S.3, 2018, s.1-18.

TUOR, Peter/SCHNYDER, Bernhard/SCHMID, Jörg/RUMO-JUNGO, Alexandra: Das Schweizerische Zivilgesetzbuch, 12. Auf., Zürich-Basel-Genf 2002.

VELIDEDEOĞLU, Hıfzı Veldet/ATAAY, Aytekin: Türk Cemiyetler Hukuku, İstanbul 1956.

YILMAZ, Canan: Uluslararası belgelerde ve Türk Hukukunda dernek özgürlüğü, Yayımlanmamış Yüksek Lisans Tezi, İstanbul 2008.

ZEVKLILER, Aydın/ERTAŞ, Şeref/HAVUTÇU, Ayşe/ACABEY, M. Beşir/GÜRPINAR, Damla: Yeni Medenî Kanuna Göre Medenî Hukuk (Temel Bilgiler), 10. Bask1, Ankara 2018.

ZEYTIN, Zafer/ERGÜN, Ömer: Türk Medenî Hukuku, 4. Baskı, Ankara 2018. 